\title{
LEGITIMIZING AND ReSISTANCE IDENTITIES IN IMMIGRANT STUdeNTS' SCHOOL ESSAYS: Towards a Culturally Sustaining Pedagogy
}

\begin{abstract}
The aim of this paper is to show that the ambivalent identities projected by immigrant students could serve the goals of a culturally sustaining pedagogy which seeks to perpetuate cultural pluralism at school. In our view, language teaching should not limit itself to correcting their lexicogrammatical "errors", but could also concentrate on the content of immigrant student essays, so as to bring their identities to the surface. To this end, we investigate the ways young immigrants living in Greece position themselves towards the dominant assimilationist discourse in Greek society. We discuss immigrant students' ambivalent identities showing their wish to legitimize themselves as members of the host community and simultaneously to resist its monoculturalist pressures. We finally argue for the exploitation of immigrant students' texts involving their experiences and identities: such texts could enhance all students' critical language awareness and could foster multiculturalism and multilingualism at school.
\end{abstract}

Keywords

Immigrant school essays; legitimizing and resistance identities; assimilation; critical language awareness; culturally sustaining pedagogy

\section{Introduction}

When the influx of immigrants started in Greece at the beginning of the 1990s, Greek people were faced with a situation they were totally unfamiliar with. Focusing on education, it should be noted that Greek schools were unprepared to cope with immigrant and local students together in the same classes. More than twenty years later, immigrant students have eventually surpassed the $10 \%$ of the 
student population in Greek schools. However, Greek educational practices essentially remain monocultural and assimilationist (Boutoulousi 2002: 45, 57, Gogonas 2010).

Such observations bring to the surface the nation-centered, assimilationist, and eventually racist character of the Greek school and society in general, where immigrant students are expected to live and work. In this paper, we focus on the discursive ways immigrant students attending Greek Lyceums (15-18 years old) position themselves towards the assimilationist, racist discourses surrounding them. In particular, we have identified several versions of the disclaimer I am adjusting myself, but.... which will be analyzed here. Immigrant students seem to construct ambivalent identities revealing their tendency both to comply with assimilationist pressures so as to legitimize themselves as members of the host community, and to resist such pressures by highlighting aspects of their own immigrant experiences.

Last but not least, we would like to argue for the exploitation of such material for raising students' critical language awareness in class. Immigrant students' essays are more often than not collected and analyzed for their lexicogrammatical "errors" and this kind of analysis aims at improving L2 teaching methods. Here we would like to suggest that language teaching concentrating on the content of such texts and on the identities included therein could enhance immigrant and, most importantly, non-immigrant students' critical language awareness of their own latent assimilationist and monoculturalist ideologies, and could eventually promote a culturally sustaining pedagogy (Paris 2012).

To this end, Section (2) refers to the theoretical background of the study involving a combination of critical discourse analysis, the social constructionist approach to identities, and the distinction between legitimizing and resistance identities, while Section (3) provides an account of how monolingualism and monoculturalism are naturalized and perpetuated in the Greek context and how this affects language teaching addressed to immigrants. The data collection process is described in Section (4) and its analysis is included in Section (5). Immigrants' ambivalent identities, as revealed by the analysis of our data, form the basis for arguing in favor of exploiting immigrant texts and identities in language teaching (Section 6).

\section{The theoretical background of the study}

The analytical framework of the present study combines critical discourse analysis, the social constructionist approach to identities, and the distinction between legitimizing and resistance identities.

First, the main goal of critical discourse analysis is to unveil the discursive ways social inequality is reproduced and to denaturalize such reproduction (see among others Fairclough 1989; van Dijk 2008; Wodak and Meyer 2001). Moreover, critical discourse analysis explores ways of positioning towards this natu- 
ralized reproduction of social inequality via discourse (Blommaert 2005). One of its most important principles concentrates on the relation between the macro-level involving the dominant (social, linguistic, educational, etc.) values and views, and the micro-level involving the discoursal strategies and texts produced by individuals (van Dijk 2008: 85-89). Our analysis is placed within this framework, also exploiting concepts such as intertextuality and entextualization. Our research question revolves around how immigrant students employ the disclaimer I am adjusting myself, but... in order to discursively position themselves towards the assimilationist, racist discourses surrounding them. Via this disclaimer immigrant students construct ambivalent identities combining assimilation and resistance features.

Within the social constructionist paradigm, identities are not something people are born with/into, but something they construct via their semiotic behavior. Discourse and other semiotic resources (e.g. image, music) allow us to signify specific aspects of ourselves, thus including us in specific sociocultural groups and excluding us from others (see among others Benwell and Stokoe 2006, Archakis and Tsakona 2012 and references therein). As Castells (2010: 7) suggests,

all identities are constructed. The real issue is how, from what, by whom, and for what. The construction of identities uses building materials from history, from geography, from biology, from productive and reproductive institutions, from collective memory and from personal fantasies, from power apparatuses and religious revelations. But individuals, social groups, and societies process all these materials, and rearrange their meaning, according to social determinations and cultural projects that are rooted in their social structure, and in their space/time framework.

Castells (2010) distinguishes between legitimizing and resistance identities, which emerge in all contexts marked by power relations. Legitimizing identities are "introduced by the dominant institutions of society to extend and rationalize their domination vis à vis social actors" (Castells 2010: 8). In Castells' conceptualization, legitimizing identities prolong the dynamics of the state and are deeply rooted among people (Castells 2010: 9).

On the other hand, resistance identities are

generated by those actors who are in positions/conditions devalued and/or stigmatized by the logic of domination, thus building trenches of resistance and survival on the basis of principles different from, or opposed to, those permeating the institutions of society (Castells 2010: 8).

Such identities result in the formation of communities whose main aim is the "collective resistance against otherwise unbearable oppression, usually on the basis of identities that were, apparently, clearly defined by history, geography, or biology, making it easier to essentialize the boundaries of resistance" (Castells 2010: 9; see 
also Castells 2010: 421-422). This conceptualization of identities highlights the fact that they are interactively constructed: "participants position themselves with regards not only to each other, but also to the ways in which they are defined by discourses $[\ldots]$ which circulate mass media, institutions and everyday contexts" (Lo and Reyes 2004: 118; see also Castells 2010: 11-12, 421-422).

In what follows, we will discuss the macro-level, which, as already mentioned, involves the dominant (social, linguistic, educational, etc.) values and views, that is, the dominant discourses via which social reality is represented and organized (see among others Gee 1996). Immigrant students' legitimizing and resistance identities seem to be built in relation to such discourses.

\section{From monoculturalism and monolingualism towards a culturally sustainable pedagogy}

Contemporary approaches to multilingualism and multiculturalism aim, among other things, at dispelling discrimination against multi/bilingual speakers and denaturalizing monolingualist and monoculturalist ideologies. Indeed, speakers may commonly use diverse linguistic resources without always considering whether these linguistic resources "belong to" specific languages or varieties (Lytra and Jørgensen 2008: 5-6; see also Creese et al. 2008 and references therein). This, however, does not mean that multiculturalism and multilingualism have been unanimously accepted as mainstream practices and core values in contemporary nation-states. On the contrary, in most Western states multiculturalism and multilingualism are still conceived as problems to be solved. Since the beginning of the $19^{\text {th }}$ century, the intense preoccupation with the standardization and codification of languages and the ideological association of monolingualism and nationhood, among other factors, have led to "enduring monolingual ideologies" (our emphasis), especially in political and public discourse, thus undermining and stigmatizing languages spoken by minority groups (Martin-Jones et al. 2012: 2-3; see also Dendrinou 2001). Consequently, the quest for national unity and the avoidance of diversity emerge as core values in Western civilization. This is achieved through various institutions, mostly through (language) education (Blommaert and Verschueren 1998: 117 ff., Macedo et al. 2010: 135-166).

Greece is no exception to that. As Kiliari (2005: 25-34, 111-154) observes, language policy in Greece has traditionally favored monolingualism and monoculturalism: minority languages (even indigenous ones) have more often than not been stigmatized and eventually become "invisible" in Greek education and society in general. It is taken for granted that immigrant or other minority children "will" learn Greek and (sooner rather than later) "will" abandon their heritage languages and cultures. In other words, assimilationist discourses addressed to immigrant populations could be formulated as follows: immigrants coming to Greece are expected to learn Greek as if it were their mother tongue, to accept the Greek culture, and to leave their own linguistic and cultural characteristics 
behind. Furthermore, the low prestige social roles and professions assigned to them are presented as the "best" the Greek society can offer, and are not perceived by Greeks as indicative of racist practices and views. Such majority expectations become a significant part of the context where immigrants work and live (Sapountzis et al. 2006, Sapountzis 2013).

In Greek schools, immigrant students are faced with similar majority expectations and stereotypes. Even though many of them have been born in Greece and may speak Greek even at home with their family, their oral or written discourse is in constant comparison with the discourse produced by majority students, and is therefore assessed as "full of errors" that a "native speaker" of Greek would not make. In other words, immigrant students' discourse attracts both teachers' and researchers' attention exclusively on the basis of its "deviations" from majority students' discourse. Lexicogrammatical "deviations" and "errors" thus become the main focus of the language teaching addressed to immigrant students, while their correction emerges as the basic aim of language teaching and relevant research (see among others Tzimokas 2010, 2015, Tantos et al. 2015 and references therein). Such practices and views reflect the so-called deficit approaches to language teaching which were popular in the 1960s and 1970s and

viewed the languages, literacies, and cultural ways of being of many students and communities $[\ldots]$ as deficiencies to be overcome in learning the demanded and legitimized dominant language, literacy, and cultural ways of schooling (Paris 2012: 93; see also the references therein).

Here, we would like to propose a shift of focus when it comes to immigrant students' discourse, in particular their written school essays. In our view, language teaching should not limit itself to pointing out and correcting lexicogrammatical "errors", but could also concentrate on the content of student essays, so as to bring to the surface immigrant students' positionings and identities. Immigrant students' perceptions and representations of social reality are more often than not excluded from the teaching materials employed in class, thus by default promoting dominant, majority perceptions and values. If, however, our goal is to embrace multi/interculturalism and multilingualism in school or other social contexts, immigrant students' discourse ought to provide us with such an opportunity: it could help us enhance all students' critical language awareness of their own sociopolitical and linguistic ideologies concerning minorities in particular and social inequality in general (see Fairclough 1989: 238-239, Archakis and Tsakona 2012: 125-128). Instead of trying to impose dominant social and linguistic norms on immigrant students, we could strive for what Paris (2012) calls a culturally sustaining pedagogy which "seeks to perpetuate and foster - to sustain - linguistic, literate, and cultural pluralism as part of the democratic project of schooling" and "support[s] young people in sustaining the cultural and linguistic competence of their communities while simultaneously offering access to dominant cultural competence" (Paris 2012: 93, 95). 
In the following Sections, we will try to show that the ambivalent identities projected by immigrant students could serve the above mentioned pedagogical goals. More specifically, we will investigate the ways young immigrants position themselves towards the assimilationist and homogenizing discourse that prevails in the Greek society in general (even if not all Greek citizens agree with it). Our analysis aims to investigate the identities constructed via the disclaimer $I$ am adjusting myself, but... We will argue that this disclaimer is a very efficient discursive means that gives immigrant students the opportunity to express their need for adjustment to the host country as well as their reluctance to forget their own cultural and immigrant experiences.

\section{The data of the study and the data collection process}

In the framework of the research project Education for Foreign and Repatriate Students under the auspices of the Aristotle University of Thessaloniki, Greece, the research team of the University of Patras visited approximately 50 schools (including Primary schools, High schools and Lyceums) in Attica and the Peloponnese, Greece, and handed over questionnaires investigating immigrant students' attitudes towards their heritage languages and the Greek language.

Students were also asked to take the position of an immigrant friend of theirs and write a letter about what troubles and what pleases them in the new place of residence. Our expectation was that our immigrant students would draw from their own experiences or from those of their relatives, which was what happened in most cases. It should be noted that the teacher's role was - to a considerable extent - performed by the researcher, after both the teacher and the school director gave their permission. In the present study, we concentrate on essays collected from Lyceums (for students from 15 to 18 years old), in particular on 118 essays collected from 8 Lyceums situated in different parts of the Peloponnese. Their authors were bilingual speakers, mostly of Albanian origin, but also of Russian, Bulgarian, Polish, Moldavian, Ukrainian, etc. origin.

The present discussion will focus upon 12 essays $(10.1 \%)$ where the disclaimer I am adjusting myself, but... appears. Although the disclaimer surfaces in a limited number of essays, we would like to point out that its combination of assimilationist and resistance elements is particularly important and interesting. Its limited appearance in this set of data could be considered indicative of the fact that the essay writing process does not seem to be the appropriate locus for immigrant students' attempt to articulate a complex voice diverging from the expected full compliance with the educational and social normative discourse of the majority. However, the fact that some of these students have chosen, after all, to articulate their ambivalent voices in such an educational context deserves our attention. 


\section{Data analysis}

The aim of the analysis ${ }^{1}$ is to help us understand the function of the disclaimer representing immigrant students' complex and polyphonic voice. The analysis is mainly qualitative and not quantitative, as it does not take into consideration social factors, such as immigrant students' place of origin, gender, age, fluency in Greek, time of stay in Greece, their parents' occupation, etc. Such an approach would presuppose a different research design, hence it goes beyond the limits of the present study. In what follows, we move from the macro-level to the microlevel, as we concentrate on students' texts and identities.

Our first goal is to explore the manifest intertextual link between two similar disclaimers with different targets, i.e. the I'm not a racist, but... (targeting immigrants) and the I am adjusting, but... (targeting the majority). Both of them overtly draw upon the same oppositional schema (see Fairclough 1992: 84). In the I'm not a racist, but... disclaimer, the initial positive self-presentation of majority speakers is followed by a negative other-presentation of immigrants introduced with but (e.g. but they break into our houses) (van Dijk 1992). Something similar is attested in the disclaimer of the essays examined here. Contrastive markers



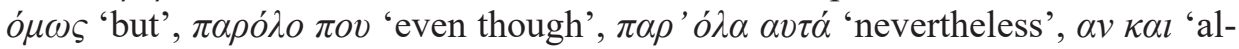
though', introduce the second part, where, in spite of majority expectations, immigrants refuse to assimilate and accept majority values. More specifically, in the second part, immigrant students (a) refer to their experiences and memories as victims of racist attitudes and attacks (see examples of Group A below); (b) refer to the fact that they miss their friends and relatives from their country of origin (see examples of Group B below).

Following Castells' (2010) distinction (see Section 2), it could be suggested that in the first part of the disclaimer immigrant students construct legitimizing identities indicating their willingness and effort to align themselves with the Greek context and the expectations of the Greek majority. In other words, they adopt the identities proposed or assigned to them by dominant discourses and institutions, so as to gradually become "legitimate" members of the host community and eventually to confirm the power of the state and other institutions over themselves. The second part of the disclaimer reveals a clash with dominant ideologies and expectations: immigrant students seem to be reluctant to overlook the racist behaviors they suffered from, and to forget their affection for their homeland and its people. Thus, they construct identities indicative of their resistance to totally conform to majority norms and discourses, which would entail forgetting racist attacks and/or their beloved ones back home. The following examples are illustrative of such ambivalent identities. 


\section{GROUP A}

Remembering racist behaviors as resistance ${ }^{2}$

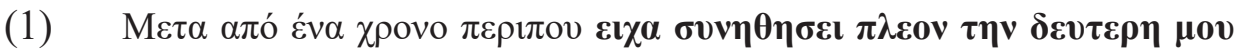

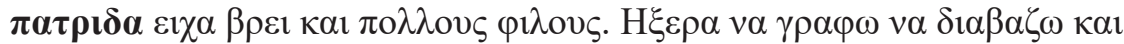

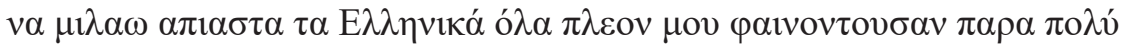

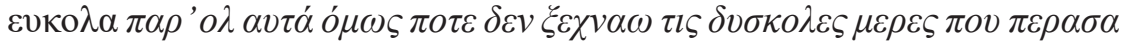



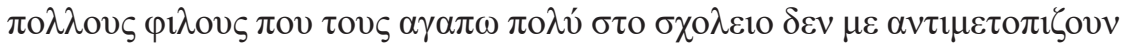

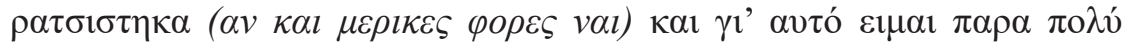

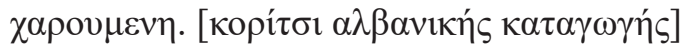

After a year or so I had at last got used to my second homeland [i.e. Greece] I had also made many friends. I knew how to write to read and to speak Greek fluently everything seemed very easy after all nevertheless I never forget the difficult days I had at the beginning. Right now I like Greece very much I have many friends whom I really love I am not treated in a racist manner at school (although sometimes I am) and that's why I am really happy. [girl of Albanian origin]

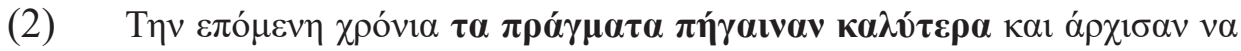

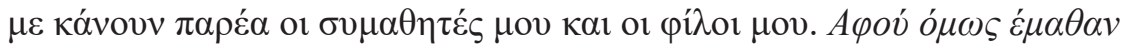

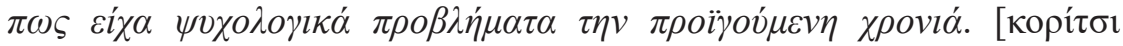



The following year things went better and my schoolmates and my friends started to hang out with me. But [this happened] after they found out that I was having psychological problems during the previous year. [girl of Moldavian origin]

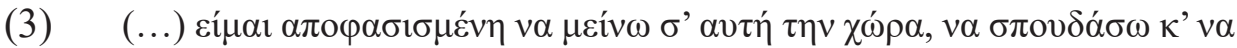

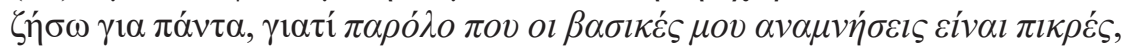

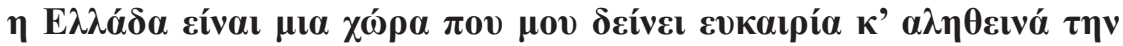

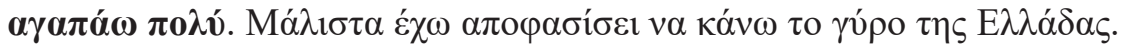

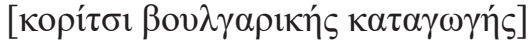

(...) I am determined to stay in this country, to study and to live here forever, because even though my main memories are bitter, Greece is a country that gives me an opportunity and honestly I really love it. In fact I have decided to travel all around Greece. [girl of Bulgarian origin]

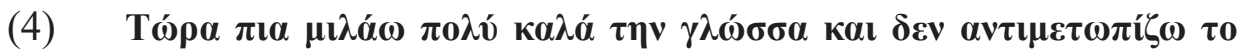

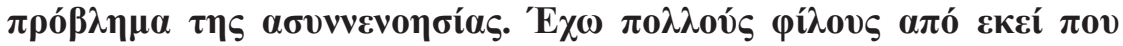




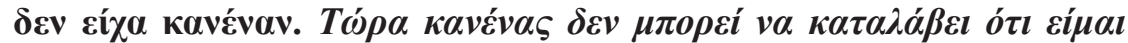

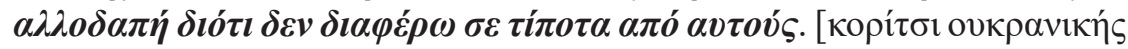

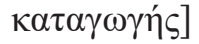

Now I speak the [Greek] language very well and I don't face communication problems. I have many friends even though at the beginning I had none. Now nobody can tell that I am a foreigner because I am not any different from them at all. [girl of Ukrainian origin]

In extracts 1-4, in the first part of the disclaimer, immigrant students express their positive attitudes and adjustment to the majority context in various ways:

$\alpha \pi$. 1i $\varepsilon \iota \alpha \alpha \sigma v v \eta \theta \eta \sigma \varepsilon เ \pi \lambda \varepsilon 0 v \tau \eta v \delta \varepsilon v \tau \varepsilon \rho \eta \mu 0 v \pi \alpha \tau \rho เ \delta \alpha$

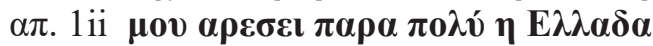

$\alpha \pi .2 \tau \alpha \pi \rho \alpha ́ \gamma \mu \alpha \tau \alpha \pi \eta ́ \gamma \alpha \iota v \alpha v \kappa \alpha \lambda v ́ \tau \varepsilon \rho \alpha$

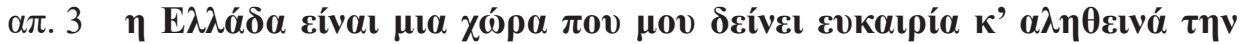

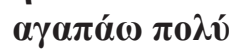

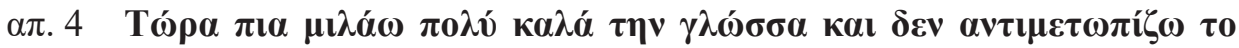



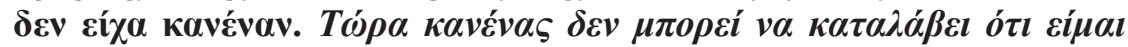

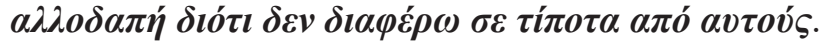

ex. 1i I had at last got used to my second homeland [i.e. Greece]

ex. 1ii I like Greece very much

ex. 2 things went better

ex. 3 Greece is a country that gives me an opportunity and honestly I really love it

ex. 4 Now I speak the [Greek] language very well and I don't face communication problems. I have many friends even though at the beginning I had none. Now nobody can tell that I am a foreigner because I am not any different from them at all

Via such expressions, immigrant students construct legitimizing identities: they adopt the majority perspective and hence appear to gradually accept the conditions and values of their new place of residence, and to develop bonds with the members of the majority. Immigrant communities' expectations according to which immigrant students should keep and display strong bonds with their homeland and assign a prominent position to it, seem to be ignored in the first part of the disclaimer. Only later on are the initial acceptance and consent mitigated and partly revoked by expressions resisting the total acceptance of majority norms and behaviors:

$\alpha \pi$. 1i $\pi \alpha \rho{ }^{\prime} \circ \lambda \alpha v \tau \alpha \dot{o} \rho \omega \omega \varsigma \pi o \tau \varepsilon \delta \varepsilon v \xi \xi \chi v \alpha \omega \tau \iota \varsigma \delta v \sigma \kappa o \lambda \varepsilon \varsigma \mu \varepsilon \rho \varepsilon \varsigma \pi o v \pi \varepsilon \rho \alpha \sigma \alpha \sigma \tau \eta v$ $\alpha \rho \chi \dot{\eta}$ 


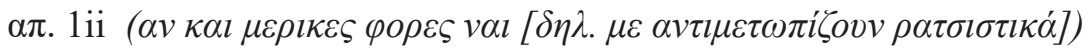

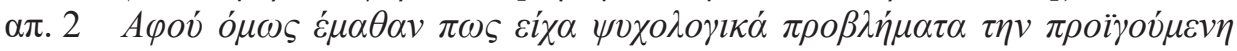
$\chi \rho o v i \alpha ́$

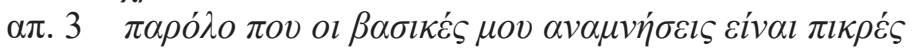





ex. $1 \mathrm{i}$ nevertheless I never forget the difficult days I had at the beginning

ex. 1ii (although sometimes I am [treated in a racist manner])

ex. 2 after they found out that I was having psychological problems during the previous year

ex. 3 even though my main memories are bitter

ex. 4 Now nobody can tell that I am a foreigner because I am not any different from them at all

Such utterances refer to immigrant students' negative experiences with members of the majority: adjustment difficulties, racist behaviors, psychological problems due to their schoolmates' rejection, denigration by the majority. In general, the negative experiences attested in the second part of examples 1-4 result from, or are directly related to, social exclusion, in spite of the fact that immigrant students express their "love" for their "second homeland", that is, Greece. This is illustrated in example 2, where the student reports that she started enjoying her schoolmates' company only when the latter felt sorry for her psychological problems caused by their rejection in the past. In example 4, the student also clearly implies that she felt excluded by majority schoolmates. In example 1, the disclaimer is used twice to denounce racist behaviors of the majority, despite the writer's positive framing and conclusion (that's why I am very happy). The second part of example 3 also has a resisting content as it hints at majority's racist behavior. ${ }^{3}$ However, it seems to lose its emphatic function since it precedes the positive one that underlines the student's adjustment.

In example 4, the contrast between the first and the second part is implied rather than clearly stated. A close examination of the sentence Now nobody can tell that I am a foreigner because I am not any different from them at all reveals that, contrary to what happens now, in the past this student was perceived by majority members as a foreigner who was "different" than "them". In general, the pronouns they/them are used to refer to the members of the outgroup, namely those excluded from we/us. Although the student states that she no longer differs from majority students, she uses the pronoun they to highlight the clear distinction still prevailing between her immigrant group (we/us) and the majority (they/them).

The analysis has so far shown that, in the examples belonging to Group A, the disclaimer consists of a first part referring to the graded adjustment to the new place of residence, thus constituting a legitimizing identity, and of a second part resisting total assimilation by evoking adjustment difficulties. 
Such observations allow us to trace the entextualization process of the disclaimer in question, i.e. how the disclaimer I'm not a racist but..., used by majority people, is "recontextualized" and becomes "a new discourse" (Blommaert 2005: 47), that is, the disclaimer I am adjusting myself, but... used by immigrant students. Here it is crucial to realize that, while the disclaimer of the majority constitutes a covert attack against immigrants, the disclaimer of the immigrants does not only resist majority expectations and practices, but simultaneously shows immigrants' eagerness to be accepted. Immigrant students underline their satisfaction for getting used to the new environment of the host country and express their determination to stay (see e.g. examples 1 and 3). However, via keeping the memories of their hard times alive, they attempt to counterbalance the compromise of their heritage cultural background (due to their declared loyalty to their new homeland). To sum up, the entextualization process of the original disclaimer, i.e. its exploitation in a new context by immigrant students, leads to a new version which reverses the target, resists majority values, and simultaneously highlights immigrant students' effort to adjust, thus legitimizing themselves as ingroup members.

\section{GROUP B}

Homesickness as resistance

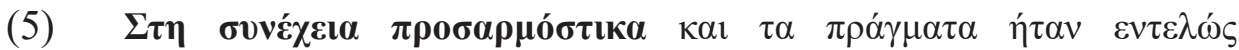





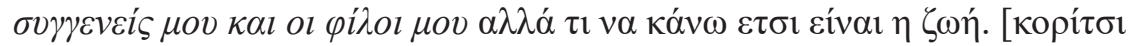
$\alpha \lambda \beta \alpha v i \kappa n ́ s ~ \kappa \alpha \tau \alpha \gamma \omega \gamma \eta ́ s]$

Later on I adjusted myself and things were totally different. I made friends I did really well at school and so I don't have that much of a problem. Of course I miss my relatives very much and my friends but what can I do that's life. [girl of Albanian origin]

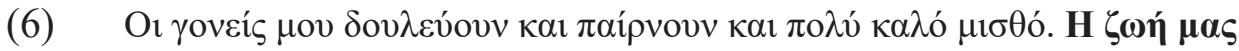

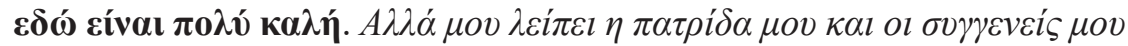



My parents work and their salary is very good. Our life here is very good. But I really miss my homeland and my relatives. [girl of Albanian origin]

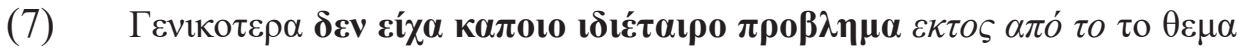

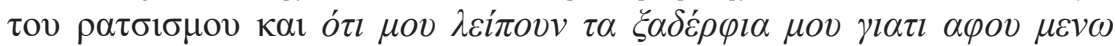

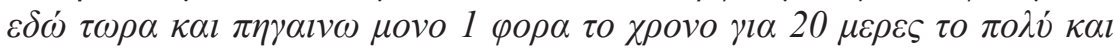




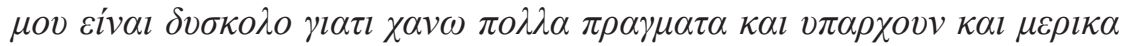

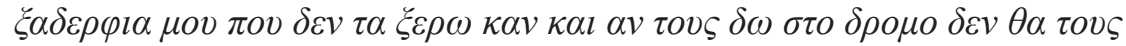

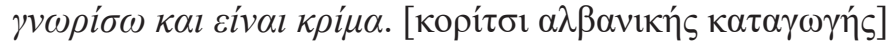

In general I didn't have any particular problem except for the racism issue $^{4}$ and the fact that I miss my cousins because now that I live here I only visit [them] once a year for 20 days at most and it is hard for me because I am missing many things and there are some cousins of mine I haven't even met and if I see them on the street I won't recognize them and it's a pity. [girl of Albanian origin]

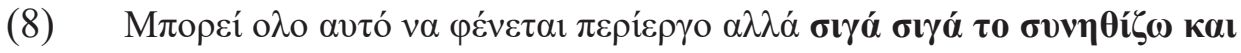

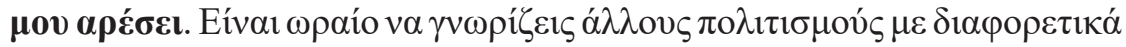

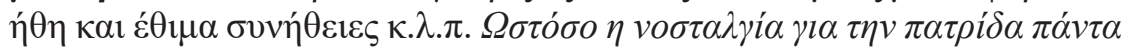

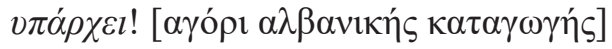

It might sound strange but I gradually get used to it [i.e. the new place] and I like it. It's good to get to know different cultures with different manners and customs habits etc. However, the homesickness for my country always remains! [boy of Albanian origin]

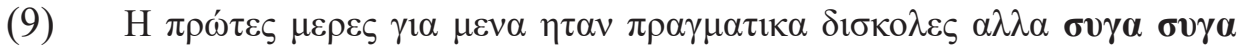

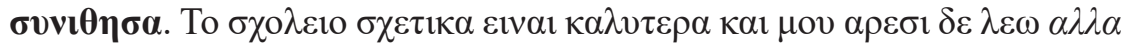

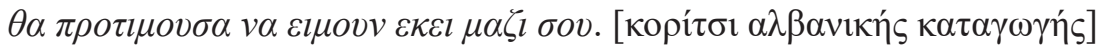

For me the first days were really difficult but gradually I got used [to the new place]. School is relatively better and I like it I admit it but I would rather be there with you. [girl of Albanian origin]

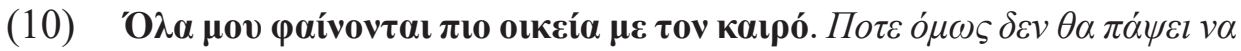

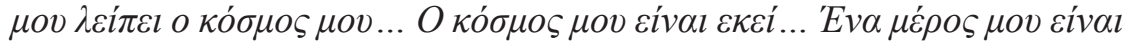

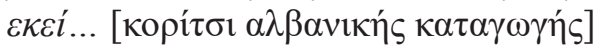

Everything seems to me more familiar as time goes by. But I will never stop missing my world... My world is there... A part of me is there... [girl of Albanian origin]

In examples 5-10 we can identify the following positive attitudes and adjustment to the majority context:

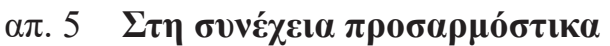

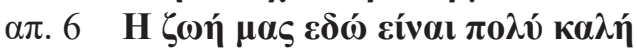

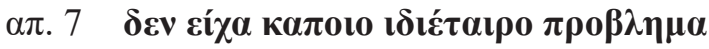

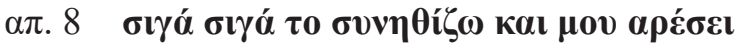


$\alpha \pi .9 \sigma v \gamma \alpha \sigma v \gamma \alpha \sigma v v i \theta \eta \sigma \alpha$,

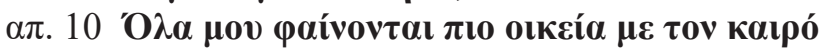

\section{ex. 5 Later on I adjusted myself \\ ex. 6 Our life here is very good \\ ex. 7 In general I didn't have any particular problem \\ ex. 8 I gradually get used to it [i.e. the new place] and I like it \\ ex. 9 gradually I got used [to the new place] \\ ex. 10 Everything seems to me more familiar as time goes by}

Such expressions (cf. examples 1-4) allow immigrant students to show their adjustment to the new country. They therefore constitute an effort to create bonds with the majority. By embracing majority values, immigrant students attempt to strengthen the solidarity bonds between the two groups, and hence to construct legitimizing identities.

However, from an ingroup immigrant perspective, this alignment with majority assumptions would compromise their heritage identity. So, the alignment is mitigated via the second part of the disclaimer:

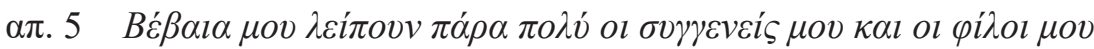

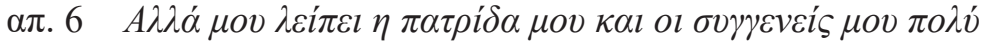

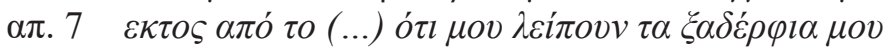

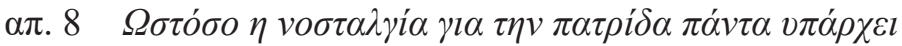

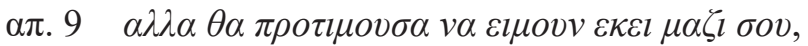

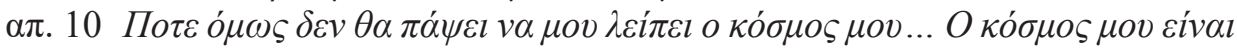

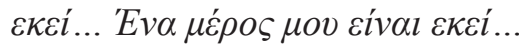

ex. 5 Of course I miss my relatives very much and my friends

ex. 6 But I really miss my homeland and my relatives

ex. 7 except for (...) the fact that I miss my cousins

ex. 8 However, the homesickness for my country always remains

ex. 9 but I would rather be there with you

ex. 10 But I will never stop missing my world... My world is there... A part of me is there...

The contrast identified in the extracts above stems from immigrant students' need to connect with their family and friends in their countries of origin. Immigrant students show that, despite their effort to adjust, there is an empty space in their lives that can only be filled by friends and relatives from "home", not by new friends and relations in the host country. By admitting their (strong) wish to maintain their bonds with people from their homeland and, if possible, to get back there sometime, their initial statement of adjustment is compromised and immigrant students clearly distinguish themselves from the majority. Consequently, they reveal both their partial acceptance of majority values and their partial integration in the host 
community. In this sense, they resist the assimilationist values of the majority, since not here, in Greece, but there, namely in their countries of origin, are their relatives, their friends, their world, the homeland (see example 10). Such acts in the second part of the disclaimer are graded in resisting potential: resistance is minimum when they only say that they miss their friends and relatives (examples $5-7),{ }^{5}$ it becomes stronger when they appear to be homesick (example 8), and it culminates when there is used (examples 9-10) via which immigrant students make a mental move from the "hard", inhospitable and (to a certain degree) rejected here, namely their present place of residence, to the "familiar" there of the homeland.

What is more, by presenting themselves as homesick and by wishing to return there, immigrant students highlight the positive influence and the significance of their own cultural background and context. Therefore, such utterances in the second part of the disclaimer perform self-determination acts that attribute to immigrant students a sense of cultural pride which is also indicative of their resistance to assimilation (see also the analysis of examples 1-4).

Rounding up the discussion of Group B examples, the disclaimer includes a first part showing the students' acceptance of the new context and their gradual adjustment to it, and a second part of graded resistance. In both Group A and Group B examples, the disclaimers begin with the construction of legitimizing identities showing immigrant students' willingness to adjust to majority values and expectations, while they end with the construction of resistance identities. In Group A, resistance takes the form of remembering racist attacks, while, in Group B, it takes the form of affection and homesickness towards the homeland and its people. Thus, the initial disclaimer I am not a racist, but... targeting immigrants is entextualized so as to allow for the projection of ambivalent immigrant identities.

\section{Concluding remarks and some pedagogical implications}

The central question of this study pertains to the ways immigrant students in Greece discursively position themselves towards the assimilationist, racist discourses surrounding them. The data analysis has shown that in their school essays, and under the influence of their immigrant/ethnic communities and their negative experiences in the host country, immigrant students recontextualize the original disclaimer I'm not a racist, but... used by the majority population. The disclaimer seems to have undergone an entextualization process that has led to the new disclaimer I am adjusting myself, but..., which is intertextually linked with the former, but reversing its target. While majority disclaimers are expressions of latent racism, the ones discussed here involve the construction of ambivalent identities showing immigrant students' wish to "legitimize" themselves as members of the host community and simultaneously to resist its assimilationist and monoculturalist pressures.

An important parameter of the present analysis involves the interaction between the macro-level, here the wider assimilationist context in Greece, and the 
micro-level, here immigrant students' disclaimers in their essays shaped by their living memories. In the first part of such disclaimers, students evoke the dominant, assimilationist majority views with which they seem to comply at first. Then, in the second part, they project their resistance which mitigates or challenges the initial compliance. This combination of first and second parts constructs immigrant students' voices which, while striving for adjustment in the host country, clearly state their own terms, thus building their cultural pride. Such terms involve their right to keep alive their memories from their ancestral homeland and from their (early) suffering in the host country. Maintaining the memories via the disclaimer could be seen as a particularly efficient strategy for immigrant students to keep their bonds with their past (i.e. their homeland and the experience of immigration) and to resist full assimilation without, however, precluding the adjustment to the host country. Thus, they seem to move beyond the traditional borderline between their immigrant/ethnic community and the majority population by adopting a broader and ambivalent identity that includes references both to their homeland and to the host country.

Ambivalent immigrant identities such as the ones presented here bring together elements which are normally perceived as incompatible by many members of the majority (including many majority students and teachers). The co-existence of such elements is, in our view, directly related to multi/interculturalism and respective values: the co-existence and interaction of different cultures does not necessarily imply the extinction of one of them (via, e.g., assimilation), but it could result, among other things, in the emergence of new cultural forms embracing values and practices from all the co-existing and interacting cultures. Hence, the discussion of such ambivalent and hybrid identities in class could bring to the limelight not only the diverse cultural lenses through which students view aspects of social reality, but also the processes by which speakers attempt to combine "incompatible" elements so as to construct their complex identities. Such processes and combinations lie at the heart of multi/interculturalism and, most importantly in the present context, of culturally sustaining pedagogies.

Such texts and identities hardly ever become part of the teaching material analyzed and discussed in class. Immigrant and non-immigrant students are more often than not exposed to texts echoing majority discourses and perspectives. Even when immigrant texts are discussed in class, the focus is on amending linguistic "errors" and "deviations" from what is considered to be the linguistic norm of the majority. The present analysis was intended not only to underline immigrant students' ambivalent identities but also to illustrate why such texts could enrich students' sociocultural experiences and enhance their critical language awareness of the social inequality imposed by monolingualist and monoculturalist ideologies. Immigrant students' voices could bring to the surface what remains untold at school (or in other institutional settings): immigrants' efforts to strike a balance between "legitimizing" themselves as members of the host communities and keeping their memories and experiences alive as members of a culturally different community. A culturally sustaining pedagogy (Paris 2012; see Section 
3) could encourage the exploitation of texts involving immigrant experiences and identities so as to foster multiculturalism and multilingualism at school and elsewhere (cf. Archakis and Tsakona 2012, 2013a, 2013b).

Needless to say, more research is required along these lines so as, among other things, to design specific proposals concerning how and what other teaching material including authentic and spontaneous immigrant identities could be collected. Furthermore, a more elaborate approach to pedagogical issues is deemed necessary: how could such texts be exploited in language teaching for cultivating students' critical language (and cultural) awareness and what would be the particular steps and goals of this exploitation? Our intention is to address such research questions in future publications. In any case, the important aspect of this process would, in our view, be to demarginalize immigrant experiences and identities, and to bring all students closer to non-dominant representations of social reality.

\section{Acknowledgments}

An earlier version of this paper was presented at the conference "Identity, Otherness and Citizenship in Contemporary Europe", Department of Education Sciences in Early Childhood, Democritus University of Thrace, Alexandroupoli, 5 December 2015. We would like to thank the audience for their supportive feedback.

\section{Notes}

1 The analysis draws on Archakis (2014) and has been modified to serve the purposes of the present study.

2 In the following examples, the first part of the disclaimer appears in bold and the second part in italics. At the end of each example, information is provided concerning the informant's gender and country of origin based on what students report about the language they speak at home. The grammatical "errors" and unconventional spelling of the original school essays have not been reproduced in the English translation.

Even though the extract my main memories are bitter may yield different interpretations, the co-text of the disclaimer (i.e. other extracts in this student's essay) has led us to interpret "bitter memories" as ones relating to majority's racist behaviors.

$4 \quad$ Example 7 is actually a mixed case (the only one in our sample) as its second part includes both an emotional outburst (as all the examples of Group B) and a memory of a racist experience (as the examples of Group A).

5 In example 5 in particular, the student moves back and forth: she begins with stating her adjustment, she proceeds with her reservations, and then she returns to the initial acceptance (but what can I do that's life). 


\section{References}

Archakis, Argiris (2014) 'Immigrant voices in students' essay texts: Between assimilation and pride'. Discourse \& Society 25 (3), 297-314.

Archakis, Argiris and Villy Tsakona (2012) The Narrative Construction of Identities in Critical Education. Basingstoke: Palgrave Macmillan.

Archakis, Argiris and Villy Tsakona (2013a) 'Humor, critical literacy and L2'. In Routes in Teaching Modern Greek. Supportive material for teaching Modern Greek as a second/foreign language, Articles for teaching Modern Greek as a second/foreign language, 4. Sociolinguistics. Center for the Greek Language. http://elearning.greek-language.gr/pluginfile.php/1612/mod resource/ content/3/humour.kritikos.grammatismos.pdf (accessed on 6 August 2016). [in Greek]

Archakis, Argiris and Villy Tsakona (2013b) 'Sociocultural diversity, identities, and critical education: Comparing conversational narratives at school'. Critical Literacy: Theories and Practices 7 (1), 48-62.

Benwell, Bethan and Elisabeth Stokoe (2006) Discourse and Identity. Edinburgh: Edinburgh University Press.

Blommaert, Jan (2005) Discourse: A Critical Introduction. Cambridge: Cambridge University Press.

Blommaert, Jan and Jef Verschueren (1998) Debating Diversity: Analyzing the Discourse of Tolerance. London: Routledge.

Boutoulousi, Eleni (2002) 'The multicultural school: Critical approaches and cultural awareness'. In: Avdi, Avra and Anastasia Chrysafidou (eds.) Discovering the Wealth of Diversity through Art: Meeting Proceedings of the Comenius and Education without Borders Programs, 28 March-2 April 2001. Thessaloniki: Pegasus, 39-88. [in Greek]

Castells, Manuel (2010) The Power of Identity. $2^{\text {nd }}$ edition. Malden: Wiley-Blackwell.

Creese, Angela, Taşkin Baraç, Arvind Bhatt, Adrian Blackledge, Shahela Hamid, Li Wei, Vally Lytra, Peter Martin, Chao-Yung Wu and Dilek Yağcioğlu-Ali (2008) 'Investigating multilingualism in complementary schools in four linguistic communities'. Full Research Report ESRC End of Award Report, RES-000-23-1180. Swindon: ESRC. http://www.researchcatalogue.esrc.ac.uk/ grants/RES-000-23-1180/outputs/read/8e3e4b17-a195-480b-a7b1-6f37795825d5 (accessed on 6 August 2016).

Dendrinou, Vassiliki (2001) 'Bilingualism'. In: Christidis, Anastasios-Fivos (ed., in collaboration with Maria Theodoropoulou) Encyclopedic Guide for Language. Thessaloniki: Centre for the Greek Language, 89-94. http://www.greek-language.gr/greekLang/studies/guide/thema_b5/index.html (accessed on 6 August 2016). [in Greek]

Fairclough, Norman (1989) Language and Power. London: Longman.

Fairclough, Norman (1992) Discourse and Social Change. Cambridge: Polity Press.

Gee, James Paul (1996) Social Linguistics and Literacies: Ideology in Discourses. $2^{\text {nd }}$ edition. Bristol: Taylor \& Francis.

Gogonas, Nikos (2010) Bilingualism and Multiculturalism in Greek Education: Investigating Ethnic Language Maintenance among Pupils of Albanian and Egyptian Origin in Athens. Newcastle upon Tyne: Cambridge Scholar Publishing.

Kiliari, Angeliki (2005) Multilingualism and Language Education: A Sociolinguistic Approach. Thessaloniki: Vanias. [in Greek]

Lo, Adrienne and Angela Reyes (2004) 'Language, identity and relationality in Asian Pacific America: An introduction'. Pragmatics 14 (2/3), 115-125.

Lytra, Vally and J. Normann Jørgensen (eds.) (2008) Multilingualism and Identities across Contexts: Cross-Disciplinary Perspectives on Turkish-Speaking Youth in Europe. Copenhagen: University of Copenhagen, Faculty of the Humanities.

Macedo, Donald, Panayota Gounari and Vassiliki Dendrinou (2010) The Hegemony of the English Language. Athens: Epikentro. [in Greek] 
Martin-Jones, Marilyn, Adrian Blackledge and Angela Creese (2012) 'Introduction: A sociolinguistics of multilingualism for our times'. In: Marilyn Martin-Jones, Adrian Blackledge, and Angela Creese (eds.) The Routledge Handbook of Multilingualism. London: Routledge, 1-26.

Paris, Django (2012) 'Culturally sustaining pedagogy: A needed change in stance, terminology, and practice'. Educational Researcher 41 (3), 93-97.

Sapountzis, Antonis (2013) 'Dominant group members talk about the acculturation of immigrants in Greece: Who is in charge of the acculturation process?' Hellenic Journal of Psychology 10, 24-46.

Sapountzis, Antonis, Lia Figgou, Nikos Bozatzis, Antonis Gardikiotis and Pavlos Pantazis (2006) "“Categories we share": Mobilizing common in-groups in discourse on contemporary immigration in Greece'. Journal of Community and Applied Social Psychology 23 (4), 347-361.

Tantos, Alexandros, Katerina Alexandri, Ifigeneia Dosi, Katerina Pouliou, Paraskevi Savvidou and Georgia Fotiadou (2015) 'Error analysis in the Greek Learner Corpus (GLC): Preliminary findings'. Studies in Greek Linguistics 35, 719-732. http://ins.web.auth.gr/images/MEG_PLIRI/ MEG_35_719_732.pdf (accessed on 6 August 2016). [in Greek]

Tzimokas, Dimitrios (2010) 'A corpus for learning Greek as a second language: Towards a research and teaching tool'. Studies in Greek Linguistics 30, 602-216. http://ins.web.auth.gr/images/ MEG_PLIRI/MEG_30_602_616.pdf (accessed on 6 August 2016). [in Greek]

Tzimokas, Dimitrios (2015) 'Corpus for learning Greek as a second language: Preliminary observations'. In: Kotzoglou, George, Kalomira Nikolou, Eleni Karantzola, Katerina Frantzi, Ioannis Galantomos, Marianthi Georgalidou, Vasilia Kourti-Kazoullis, Chrysoula Papadopoulou and Evagelia Vlachou (eds.) 11 International Conference on Greek Linguistics (Rhodes, 26-29 Sep-

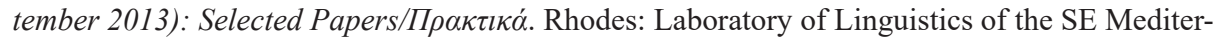
ranean, Department of Mediterranean Studies, University of the Aegean, 1679-1694. [in Greek]

Van Dijk, Teun A. (1992) 'Discourse and the denial of racism'. Discourse \& Society 3 (1), 87-118. Van Dijk, Teun A. (2008) Discourse and Power. New York: Palgrave Macmillan.

Wodak, Ruth and Michael Meyer (eds.) (2001) Methods of Critical Discourse Analysis. London: Sage.

Argiris Archakis is Professor of Discourse Analysis and Sociolinguistics in the Department of Philology at the University of Patras in Greece. He has carried out research and published extensively on the analysis of various discourse genres, such as youth conversational narratives, classroom discourse, and media discourse as well as on students' literacy. He is co-author of the book The Narrative Construction of Identities in Critical Education (Palgrave Macmillan, 2012) with Villy Tsakona. Personal webpage: http://www.philology-upatras.gr/en/staff/dep/kategetes/arcakes argures.

Address: Argiris Archakis, Department of Philology, University of Patras, Patras 26504, Rio, Greece. [email: archakis@upatras.gr]

Villy Tsakona is Assistant Professor of Sociolinguistics and Discourse Analysis in the Department of Education Sciences in Early Childhood, Democritus University of Thrace, Greece. She has published articles on humor research, political and media discourse analysis. She has co-edited Studies in Political Humor: In between Political Critique and Public Entertainment with Diana Popa (John Benjamins, 2011) and co-authored The Narrative Construction of Identities in Critical Education with Argiris Archakis (Palgrave Macmillan, 2012). Personal webpage: http://www.cultureconcept. gr/villy.tsakona.

Address: Villy Tsakona, Department of Education Sciences in Early Childhood, Democritus University of Thrace, Nea Chili, Alexandroupoli 68100, Greece. [email: villytsa@otenet.gr] 